\title{
MODELING THE INFLUENCE OF TILL RHEOLOGY ON THE FLOW AND PROFILE OF THE LAKE MICHIGAN LOBE, SOUTHERN LAURENTIDE ICE SHEET, U.S.A.
}

\author{
By JAMES E. BEGET
}

(Department of Geology and Geophysics, University of Alaska, Fairbanks, Alaska 99775, U.S.A.)

\begin{abstract}
The late Wisconsin Shelbyville till was deposited in southern Illinois c. 20000-21000 year B.P. and records the maximum southern advance of the Lake Michigan lobe of the Laurentide ice sheet. The yield strength calculated for a representative till debris flow found just south of the ice margin is $8 \mathrm{kPa}(0.08 \mathrm{bar})$, and probably approximates yield strength of basal Shelbyville till. An ice-profile model assuming plastic behavior in basal till suggests the southern Lake Michigan lobe may have been unusually thin. Reconstructed Laurentide glacier profiles from the south-west and western Great Plains (South Dakota, Alberta, Minnesota, and Montana), and the MacKenzie Delta, N.W.T., are similar to those inferred for the southern Great Lakes area, and much thinner than those of most modern ice sheets. The Pleistocene Laurentide ice sheet may have been asymmetric: thicker in the east than in the west. Glaciers resting on weak sediments can move both by subglacial sediment deformation (creep) and sliding at the sediment-ice interface. Till rheology is complex; shearing of till by over-riding glaciers would increase porosity and further reduce yield strength.
\end{abstract}

RÉsumé. Modélisation du rôle de la rhéologie des moraines basales sur l'écoulement et le profil de la surface $d u$ lobe du lac Michigan, sud de l'indlandsis des Laurentides, U.S.A. La moraine de Shelbyville a été déposée, dans le sud de l'Illinois, vers 20000-21000 B.P. Elle marque l'avance maximum vers le sud du lobe du lac Michigan de l'indlandsis Nord-américain. La résistance au cisaillement d'une coulée de moraine représentative située juste du sud du bord de l'indlandsis est de $8 \mathrm{kPa}(0,08$ bar); c'est probablement l'ordre de grandeur de la résistance au cisaillement de la moraine basale de Shelbyville. Un modèle du profil de la glace, dans l'hypothèse d'un comportement plastique de la moraine basale, suggère que l'extrêmité sud du lobe du lac Michigan a pu être inhabituellement mince. Les profils de l'indlandsis des Laurentides dans la région des grandes plaines du sud-ouest et de l'ouest (South Dakota, Alberta, Minnesota, Montana) ainsi que dans la région du delta du MacKenzie (N.W.T.) sont comparables à

\section{INTRODUCTION}

Virtually all models of glacier flow assume that glaciers rest on a rigid substrate and that movement is controled by interactions between water pressure, the rheological properties of ice, and the morphology and relief of rigid obstructions on the bedrock surface over which the glacier moves (Weertman, 1979; Paterson, 1981). Boulton and Jones (1979) have suggested that this assumption is unwarranted for parts of the southern margins of the great Pleistocene ice sheets. Both the Laurentide and Scandinavian ice sheets advanced south over regions of low relief where obstructions of pre-Quaternary bedrock were rare. The plains of the central United States and western Canada, and the northern coastal plain of Europe, are covered with ceux de la région du sud des Grands Lacs, beaucoup plus minces que ceux de la plupart des indlandsis actuels. L'indlandsis pleistocène des Laurentides a pu être asymétrique, plus épais à l'est qu'à l'ouest. Les glaciers reposant sur des sédiments facilement déformables peuvent avancer à la fois par déformation de la moraine basale et par glissement sur l'interface moraine-glace. La rhéologie des moraines est compliquée, leur cisaillement par le chevauchement du glacier accroit leur porosité et réduit leur résistance au cisaillement.

Zusammenfassung. Modellbildung für den Einfluss der Geschiebe-Rheologie auf das Fliessen und das Profil des Lake Michigan-Lobus, Süd-Laurentidischer Eisschild, U.S.A. Das Shelbyville-Geschiebe aus der spăten WisconsinVereisung wurde in Süd-Illinois etwa 20000-21000 Jahre vor der Gegenwart abgelagert und kennzeichnet den maximalen Vorstoss des Lake Michigan-Lobus des Laurentidischen Eisschildes nach Süden. Die Tragfähigkeit, berechnet für einen repråsentativen Schuttstrom gerade südlich des Eisrandes, ist $8 \mathrm{kPa}(0,08 \mathrm{bar})$, was annăhernd der Tragfăhigkeit des Shelbyville-Basisgeschiebes entsprechen dürfte. Ein Modell für das Eisprofil, das plastisches Verhalten im Basisgeschiebe annimmt, lässt darauf schliessen, dass der sũdliche Lake Michigan-Lobus ungewöhnlich dünn war. Rekonstruierte Laurentidische Gletscherprofile aus den südwestlichen und westlichen Grossen Ebenen (South Dakota, Alberta, Minnesota, Montana) und aus dem MacKenzieDelta, N.W.T., sind ahnlich denen, die für das Gebiet der südlichen Grossen Seen abgeleitet wurden und wesentlich dünner als die der neuzeitlichen Eisschilde. Der pleistozăne Laurentidische Eisschild dürfte asymmetrisch gewesen sein: dicker im Osten als im Westen. Gletscher auf weichen Sedimenten können sich sowohl durch subglaziale Deformation der Sedimente (Kriechen) wie durch Gleiten an der Berührungsfläche zwischen Sediment und Eis bewegen. Die Rheologie des Geschiebes ist kompliziert; Scherung des Geschiebes durch darüberfliessende Gletscher würde die Porosităt erhőhen und die Tragfestigkeit weiter verringern.

veneers of Pleistocene till. If the yield strength of the till sheets was significantly lower than that of ice, a significant component of Pleistocene glacier movement may have been contributed by deformation of subglacial tills.

\section{TILL YIELD STRENGTH}

It is clearly desirable to determine the yield strengths of representative Pleistocene tills at the time of deposition. It has of ten been assumed that subglacial tills must be hard and over-consolidated (Harrison, 1958; Kazi and Knill, 1969). However, modern observations of basal till exposed by glacier recession reveal that at least in some cases basal till can be soft and water-saturated (Baranowski, 1975; 
Boulton and Paul, 1976). Such tills would have low shear strength (Boulton and others, 1974). Okko (1955) described recently deglaciated basal till at Vatnajőkull as "porridge-like", and Hoppe (1952) and Gjessing (1965) called on mobile subglacial till "sludges" to account for subglacial scouring and erosion of polished bedrock whalebacks and small rock drumlins. Some models of the genesis of streamlined till drumlins and flutings require that subglacial till slurries flow to areas of low pressure, and then rapidly change geotechnical properties from low to high shear strength during dewatering and compaction (Smalley and Unwin, 1968; Menzies, 1979, 1982; Jones, 1982). The most fundamental properties of basal tills such as poor size sorting and lack of stratification, clast fabric, and progressive comminution of mineral fragments and clasts (Dreimanis and Vagners, 1971) may in some cases reflect prolonged subglacial shearing and cataclasis.

Abundant glaciotectonic features in tills, such as folds, faults, deformed beds, shear zones, and injection layers, have been described by many field workers and are further evidence that till readily deforms under glaciostatic loads (MacClintock and Dreimanis, 1964; Moran, [1971]; Ramsden and Westgate, 1971; Ochietti, 1973; Sonstegaard, 1979; Oldale and others, 1982; Nielsen, 1981; Oldale and O'Hara, 1984; Hickock and Dreimanis, 1985; Thomas and Connell, 1985). Deformation features have even been identified in Permo-Carboniferous tillite (von Brunn, 1977; Visser and Hall, 1985; von Brunn and Talbot, in press).

Shear strength of sediments is largely a function of the grain-size distribution and generally increases with clay content (Hampton, 1975; Rodine and Johnson, 1976). Yield strengths of various poorly sorted sand-silt-clay mixture similar to till range between 0 and $28 \mathrm{kPa}$ at zero normal stress (Huang, 1983). Shear strengths of representative water-saturated, unloaded tills average $10 \pm 10 \mathrm{kPa}$ (Milligan, [1976]). In contrast, peak yield strengths of water-free consolidated tills range between 150 and $250 \mathrm{kPa}$ (Selby, 1982). This suggests the yield strengths of tills of various grain-size distributions will vary greatly depending on degree of compaction, water-saturation, effective normal stress, and initial composition. Very high yield strengths will be found where clay-rich tills have been dewatered and over-consolidated; low-strength tills must be water-saturated and uncompacted. Reported values of till strength extend over two orders of magnitude, and span the value of the average yield strength of ice at $100 \mathrm{kPa}$ (1.0 bar). Stress-strain and Mohr-Coulomb failure line diagrams illustrate these geotechnical properties of till (Fig. 1).

It is possible to determine the modern rheological characteristics of tills by conducting laboratory shear-strength tests (Radhakrishna and Klym, 1974). However, measured shear strength may differ from the original shear strength, as post-depositional weathering or cementation of Pleistocene tills can substantially alter their original rheological properties (Sladen and Wrigley, 1983). The original clay matrix of many tills has been changed or removed by ground-water flow and pedogenic processes, while cementation by translocated pedogenic clays, calcite, or salts has occurred in other tills (Birkeland, 1984). Tills can develop well-defined partings and jointing during relatively short intervals of weathering, resulting in dramatic post-depositional changes in yield strength (Flint, 1971).

Another difficulty arises because laboratory tests are made on small samples of a few kilograms or less, which may not be representative of an extensive till. Tills commonly contain many large clasts which may constitute major controls on shear strength, but laboratory instruments usually can accommodate samples only as large as $2 \mathrm{~cm}$ deep by $20-30 \mathrm{~cm}$ square. Finally, the residual strength of saturated till, defined as the stress required to produce continued deformation after shear failure, probably approximates the effective yield strength of tills which are being continually sheared beneath wet-based glaciers. Unfortunately, residual strength is one of the most difficult geotechnical properties of sediments to measure in laboratory tests (Huang, 1983).

\section{YIELD STRENGTH OF THE SHELBYVILLE TILL 20000} YEARS AGO

The Shelbyville till and moraine were deposited in east-central Illinois during the most extensive late Wisconsin advance (20000-21000 year B.P.) of the Lake Michigan lobe of the Laurentide ice sheet. The till is typical of glacier deposits in the mid-West; it is as much as $25-50 \mathrm{~m}$ in thickness at the moraine front, but is typically only a few meters thick to the north of the terminal zone (Hester and DuMontelle, [1971]; Mickelson and others, 1983).

Complex end moraines define the southern perimeter of the Lake Michigan lobe (Mickelson and others, 1983). The Decatur sub-lobe protrudes south and east from the main Lake Michigan lobe and was the site of an extensive till debris flow or flow-till deposit which extended more than $3 \mathrm{~km}$ south from the glacier terminus and covered approximately $10 \mathrm{~km}^{2}$ (Fig. 2). Detailed studies of the till debris flow by Hester and DuMontelle ([1971]) indicate it is essentially identical in composition to Shelbyville till. The matrices of both consist of $33 \%$ sand, $38 \%$ silt, and $29 \%$ clay, and both are calcareous and identical in color (7.5 YR 7/3). They have identical clay-mineral ratios (three parts chlorite to two parts illite). Compositions of erratic boulders are similar in the Shelbyville till and the flow till. Stratigraphic and geomorphic relationships indicate that the flow till was contemporaneous with the local Shelbyville moraine and the maximum stand of the Lake Michigan

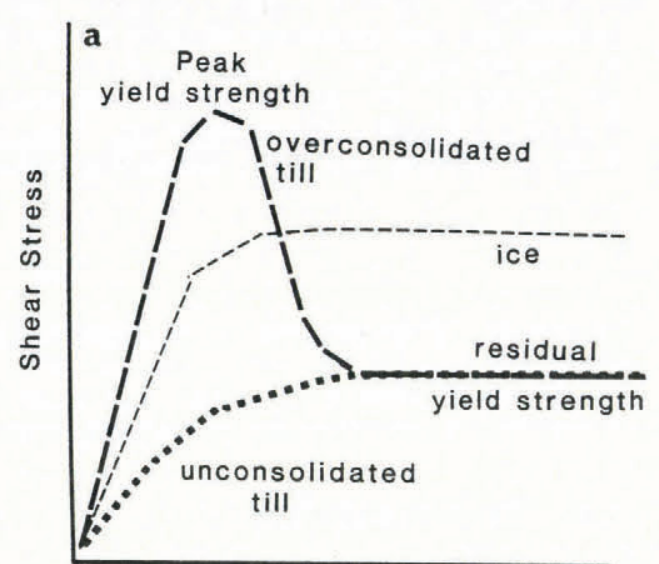

Strain

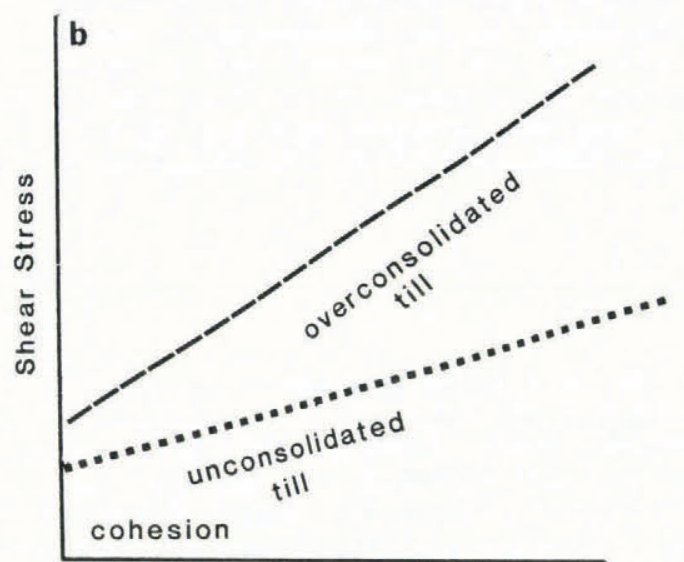

Normal Stress

Fig. 1. (a) Stress-strain diagram for over-consolidated and unconsolidated till and glacier ice. The figure is plotted for a constant effective normal stress greater than zero. As effective normal stress decreases, peak yield strength approaches residual yield strength. (b) Mohr-Coulomb failure lines for consolidated and unconsolidated till. Modified from Selby (1982) and Smalley and Unwin (1968). 


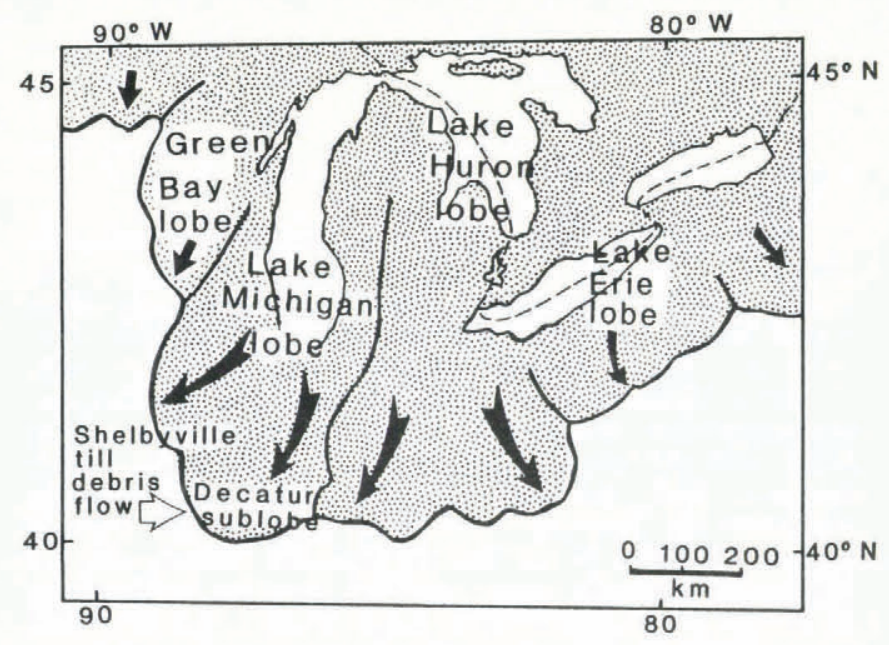

Fig. 2. Location of a large till debris flow at the terminus of the Lake Michigan lobe of the Laurentide ice sheet. Maximum late Wisconsin terminal positions of all glacier lobes shown are not synchronous. Modified from Mickelson and others (1983).

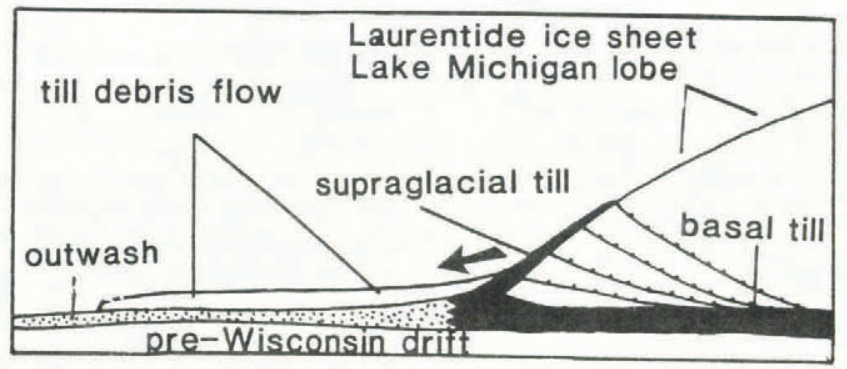

Fig. 3. Schematic diagram of the terminal zone of the Lake Michigan lobe, showing the inferred origin of the supraglacial debris which formed the large till debris flow (flow till).

lobe. The original volume of the flow was approximately $1 \times 10^{7} \mathrm{~m}^{3}$.

The close similarity between the flow till and local Shelbyville till suggests the flow till was derived from subglacial till which had been sheared into the glacier and up to the glacier surface near the ice terminus (Fig. 3). The large volume of the flow till suggests it can be considered a representative sample of the basal till, brought to the glacier surface along multiple intraglacial thrusts, and subjected to further mixing during ablation. The rheological characteristics of the debris flow, therefore, reflect a large, composite sample of Shelbyville till. It is unlikely any significant proportion of the flow till consisted of exotic supraglacial debris because multiple sedimentological studies indicate that "in most of the southern Great Lakes region ... the ice was relatively clean and only far-traveled erratics occurred above the bed of the ice" (Mickelson and others, 1983 , p. 22)

The extent of the till debris flow is easily determined from topographic maps, and the thickness of the flow till is known from 14 test borings (Hester and DuMontelle, [1971]). As shown by Johnson (1970), sediment rheology controls the morphology of a debris flow at its terminus. Bore-hole data suggest the minimum thickness of the flow till at its snout is about $1.3 \mathrm{~m}$. The surface of the flow slopes to the south at approximately $3-5 \mathrm{~m} / \mathrm{km}$. Yield strength $(K)$ of the flow till can be determined from the equation

$$
K=\rho_{\mathrm{s}} g h / \pi(1-\phi / 90)
$$

where $K$ is the yield strength, $\rho_{\mathrm{S}}$ is the sediment density, $g$ is the gravitational constant, $\phi$ is the surface slope of the flow, $\pi$ is the constant pi, and $h$ is thickness at the flow terminus (Cowan and Mansfield, 1970; Johnson, 1970). If the density of water-saturated flow till was approximately $2000 \mathrm{~kg} / \mathrm{m}^{3}$, its yield strength was approximately $8 \mathrm{kPa}$. The water-saturated debris flow was under no effective normal stress. Possible errors in this calculation may arise from the estimates of the thickness or density of the heterolithic flow till, but it is unlikely that either is off by more than $10 \%$. Because the till debris flow and the Laurentide ice sheet were contemporaneous, no post-depositional changes in the sediment could have occurred to modify the initial rheological characteristics of the till prior to the debris flow.

The rheological properties of the flow till also characterized identical Shelbyville till; shear strength of water-saturated till beneath the southern Lake Michigan lobe therefore was also approximately $8 \pm 2 \mathrm{kPa}$. If pore-water pressure in the basal till was close to the overburden pressure, the yield strength of till beneath this part of the Laurentide ice sheet was approximately $10 \%$ that of ice. Glen's flow law suggests that virtually no ice deformation would occur at $8 \mathrm{kPa}$ (Jezek and others, 1985); creep and deformation in subglacial Shelbyville till should have been much more rapid than ice deformation in the Lake Michigan lobe.

\section{LOW PROFILE OF THE SOUTHERN LAKE MICHIGAN LOBE}

Boulton and Jones (1979) have proposed that the profile of Pleistocene glaciers resting on deformable substrates should have differed from those of glaciers resting on a rigid substrate. The Lake Michigan lobe rested on deformable till with a yield strength of approximately $8 \pm 2 \mathrm{kPa}$. From Coulomb's equation, the yield strength of sediment during shear $(K)$ is dependent on effective hydrostatic pressure and cohesion $(C)$ :

$$
K=C+\tan \phi\left(\rho_{\mathrm{i}} g h-p\right)
$$

where $\rho_{j}$ is ice density, $\phi$ is surface slope, $h$ is thickness, and $p$ is pore-water pressure. If the minor thickness of sediment deforming at the ice-till interface is ignored and pore-water pressure in the basal till is assumed to have been very close to glaciostatic pressures, then the till cohesion is approximately equal to the effective yield strength of the basal till. Glacier profiles and flow should be more or less adjusted to the yield strength of the subglacial sediment, i.e. $\tau_{\mathrm{b}}=K=C$, where $\tau_{\mathrm{b}}$ is shear stress.

Following Mathews (1974), a simple expression for a glacier profile with a known, constant basal shear stress is:

$$
H=\left(2 \tau_{\mathrm{b}} L / \rho_{\mathrm{i}} g\right)^{0.5}
$$

where $H$ is glacier thickness in meters, and $L$ is distance from terminus in meters. For an average basal shear stress of $8 \mathrm{kPa}$ the equation becomes:

$$
H=1.32 L^{0.5} .
$$

The theoretical profile generated by Equation (4) is thinner than most modern glacier profiles (Fig. 4).

It is likely Laurentide glaciers south of the Great Lakes were wet-based (Sugden, 1977), but the assumption that subglacial pore-water pressures were approximately equal to glaciostatic pressures may seem problematic. However, most measurements of standing water levels in bore holes drilled in wet-based glaciers suggest overall hydrostatic pressures are quite high and generally equal to half or more of the glaciostatic load (Mathews, 1964; Boulton and Vivian, 1973; Hodge, 1976, 1979; Röthlisberger and others, 1979; Kamb and others, 1985). If some part of the abundant water at the base of wet-based glaciers is temporarily confined in pore spaces in basal till, then pore pressures could approach the glaciostatic load. This could happen when sheared, water-saturated basal till is subjected to consolidation and dewatering, especially in impermeable silty and clayey tills.

We can test the glacier profile modeled in Equation (4) and the implicit assumption of high pore-water pressure by 


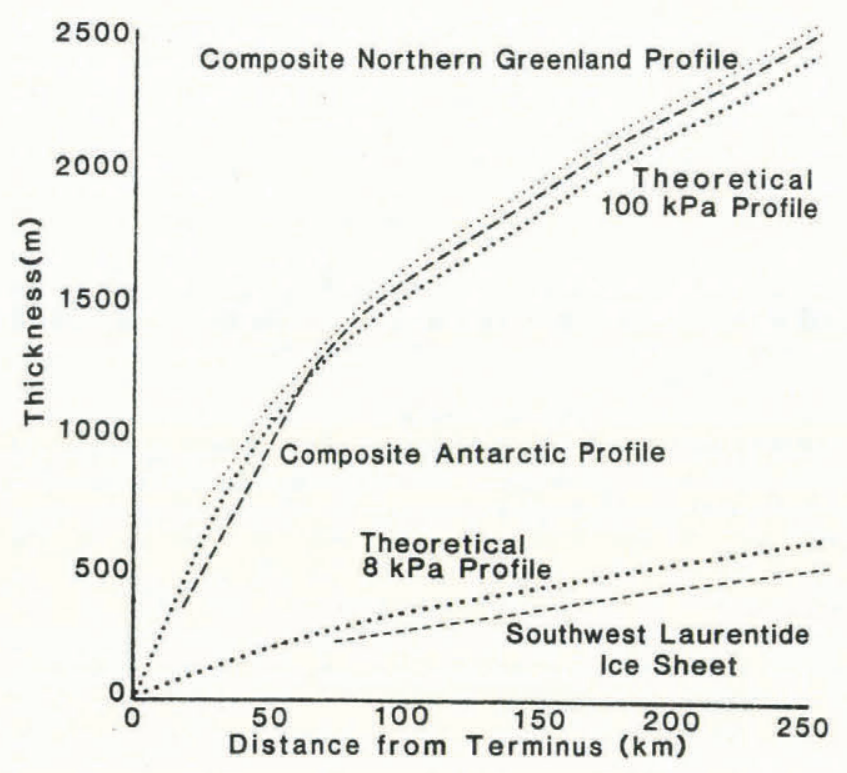

Fig. 4. The typical profiles of the northern Greenland and East Antarctic ice sheets are close to a theoretical profile, assuming perfect plasticity and a constant $100 \mathrm{kPa}$ basal shear stress. The reconstructed profiles of the south-west Laurentide ice sheet in North Dakota and the north-west Laurentide ice sheet over the MacKenzie Delta are similar to a theoretical profile, assuming a constant basal shear stress of $8 \mathrm{kPa}$, the yield strength of till in southern Illinois. The $8 \mathrm{kPa}$ theoretical profile is close to the actual profile of the southern Lake Michigan lobe c. 20000 year B.P.

comparing the theoretical profile of the Lake Michigan lobe with field data. Hester and DuMontelle ([1971]) reported that moraine profiles indicate the terminal parts of the Lake Michigan lobe rose to the north at approximately $7.6 \mathrm{~m} / \mathrm{km}$. Inserting this gradient in Equation (3) indicates that the actual Lake Michigan lobe profile at the site of the flow till, about $10-20 \mathrm{~km}$ from its terminus, can be modeled by assuming plasticity and a yield strength of $6-8 \mathrm{kPa}$. An additional estimate of the actual glacier thickness is provided by the upper limit of mapped glacier deposits in the ice-free "driftless area" of central Michigan about $400 \mathrm{~km}$ north of the glacier border (Flint, 1971). Till is found to $450 \mathrm{~m}$ elevation, while Lake Michigan at the same latitude is $180 \mathrm{~m}$ deep. The minimum thickness of the Lake Michigan lobe was therefore about $630 \mathrm{~m}$, although it must have been somewhat greater as the depth of fill in Lake Michigan since 20000 year B.P. is not known, and the ice thickness at the center of the $200 \mathrm{~km}$ wide Lake Michigan lobe must have been greater than at the lateral moraine. Equation (4) predicts a medial thickness of $835 \mathrm{~m}$. This is a reasonably good fit to the field data, especially when contrasted with the $2000-3000 \mathrm{~m}$ of thickness predicted by ice-creep models for an ice sheet resting on a rigid substrate (Sugden, 1977; Hughes and others, 1981; Hughes, 1985).

Equation (4) and independent field data agree that the profile of the southern Lake Michigan lobe was quite thin (Fig. 4). It is not known how far beyond $400 \mathrm{~km}$ from the ice limit the Lake Michigan lobe was characterized by a low profile and low basal shear stress. The width of the zone of thin glaciers is also not well known. However, some additional evidence suggests the Laurentide ice sheet may have had an unusually low profile over much of its southern and western perimeter. Wright (1973) showed that the Lake Superior lobe was thin. Mathews (1974) noted that glacier lobes in North Dakota, Montana, Alberta, and Minnesota were less than $1000 \mathrm{~km}$ thick more than $200 \mathrm{~km}$ from their termini and that basal shear stresses therefore averaged only $7-22 \mathrm{kPa}$. Field data from western and north-western Alberta show that Laurentide ice was thin in western Canada (Stalker, 1960; Westgate, 1968).
Recent mapping of Laurentide drift in the MacKenzie River delta area indicates the north-west Laurentide ice sheet also had an unusually thin profile (Hughes, 1972; Rampton, 1982). The basal shear stress beneath the late Wisconsin north-western Laurentide glacier averaged only 9-11 $\mathrm{kPa}$ (Beget, in press).

New isotopic data from apparent relict Laurentide glacier ice preserved in permafrost along the Beaufort Sea suggest that the accumulation area for Laurentide ice which flowed to the north-west was quite low, lying at perhaps as little as $700 \mathrm{~m}$ elevation (Lorrain and Demeur, 1985). Similarly, unusually rapid ice-retreat rates and minimal isostatic depression documented throughout the southern Great Lakes area and western Canada (King, 1965; Walcott, 1972; Andrews, 1973; Birchfield and Grumbine, 1985) may be explained by assuming Laurentide glaciers that reached Illinois, Michigan, North Dakota, Montana, Alberta, and the Northwest Territories were unusually thin for hundreds of kilometers from their termini. Some isostatic and field data also suggest glaciers were thin in New England (Walcott, 1972; Shreve, 1985).

In contrast, field data from nunataks on Baffin Island and eastern Canada suggest the Laurentide ice sheet was thicker in the east than in the west, and at least in some areas it was similar to modern ice-sheet profiles (Flint, 1971; Andrews, [1975]). This suggests the Laurentide ice sheet was profoundly asymmetric, at least during the last part of the Pleistocene, with the east and north-east sectors being considerably thicker than the south, south-west, west, and north-west sectors.

The mapped low-profile glaciers and the southern Lake Michigan lobe all occur in similar settings: sedimentary basins and areas of low relief at the maximum limits of ice advance, where few or no bedrock obstructions to glacier flow are present. Such conditions exist over huge expanses of central and western Canada inboard from the ice margins. If much of the central region of the Laurentide ice sheet was frozen to its bed at the height of glaciation (Hooke, 1977; Sugden, 1977), low-profile glaciers were restricted to broad terminal zones. However, as climate ameliorated and the ice sheet shrunk at the end of the last glaciation, sliding of the Laurentide glacier on deformable substrates may have occurred in areas of interior Canada that were formerly cold-based. This raises questions about the dynamics of low-profile glaciers and their importance during deglaciation. Do low-strength basal sediments make glaciers prone to surges (Clayton and others, 1985)? Do the low surface gradients of low-profile glaciers make them especially sensitive to changes in snow-line elevation and climate?

\section{SEDIMENT/GLACIER FLOW MECHANISMS}

Haeberli (1981) has criticized the theory of Boulton and Jones (1979) and other models of glacier flow calling upon sediment deformation because (1) folding and thrusting of layers of unconsolidated sediment are possible only if the sediment is frozen; and (2) the rate of erosion of the subglacial substrate may be insufficient to supply till at a rate commensurate with that required to produce glacier flow. However, the abundant field evidence of till deformation cited above indicates that plastic flow readily occurs within subglacial drift. Deformation of discrete frozen sediment layers is not required by this model.

The problem of sediment flux requires a reconsideration of the relative importance of flow mechanisms available to a glacier resting on deformable sediment. Boulton and Jones (1979) described an example of creep in subglacial sediments and showed that deformation of basal till can constitute a significant proportion of glacier velocity. However, if this is the only flow process operating, then the total volume of sediment transported to a glacier terminus must be some small proportion of the total ice volume moving through the glacier system. Most estimates of subglacial erosion rates and terminal moraine volumes are several orders of magnitude lower than Pleistocene ice flux (Flint, 1971).

This difficulty can be resolved if sliding is a significant flow mechanism for glaciers resting on 
deformable substrates (Boulton, 1982). The processes ocurring during sliding of glacier ice over a deformable substrate would be quite different from those suggested for glaciers sliding on rigid surfaces (Weertman, 1979). Regelation and enhanced ice creep would be relatively unimportant both because normal and shear stresses would be low, and because low-strength till would deform much more easily than the ice. If boulders at the ice-sediment interface interfere with sliding, they could be pushed down into the till or incorporated into the glacier sole and transported to the terminus. Till would flow to zones of low pressure in the lee of irregularities of the glacier sole as it slid over and through the till. Similar processes produce glacial flutings and possibly drumlins (Smalley and Unwin, 1968; Jones, 1982; Menzies, 1982).

The relief and rugosity of the glacier sole and not the glacier bed would be the chief obstacles to sliding. Irregularities at the base of the glacier would plow and disrupt underlying sediment, facilitating shearing, dilation, and hydrostatic inflation of the basal till. Water under pressure at the base of the glacier would occupy pore space in dilatant till, inhibiting re-consolidation and reducing effective normal stress. A principal control on the initiation of sliding would be the residual yield strength of the till, as it continuously deforms around and under glacier-sole irregularities. The strain-rate of the basal till in response to various stresses would strongly influence the glacier sliding velocity. Sliding requires a minimal flux of sediment toward the glacier terminus.

This model is illustrated in Figure 5. A relatively thin zone of till beneath the glacier, corresponding to the depth

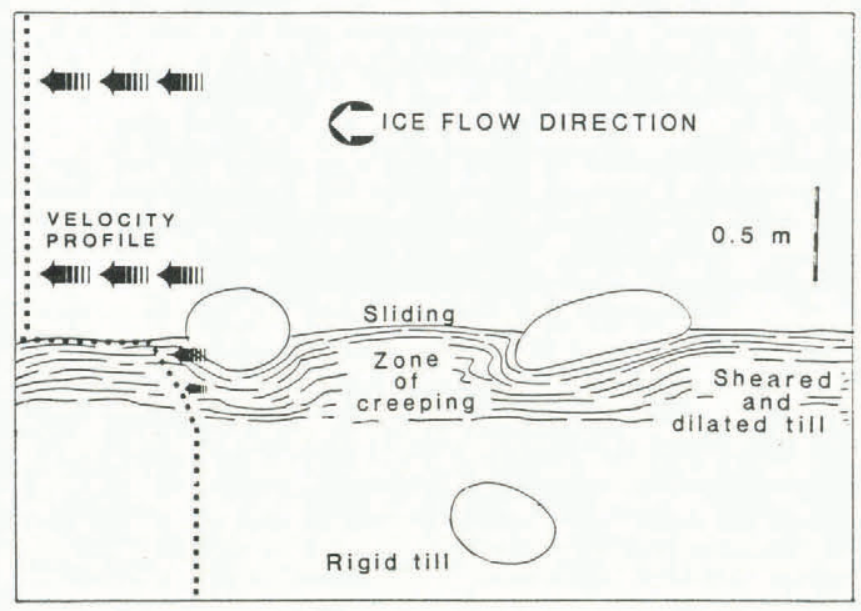

Fig. 5. Schematic illustration of a glacier sole sliding over deformable basal till. Irregularities of the ice and debris at the glacier sole disrupt and mechanically disaggregate basal till as they slide over and through it. Shearing of the till occurs as it deforms under and around the glacier base. Water occupies pore space in the sheared, dilated till. Till below the sheared zone is generally dewatered and over-consolidated. The sliding velocity is controled by till yield strength and strain-rates. Creep will occur mainly in the sheared basal till and to a lesser degree in glacier ice.

of till sheared and dilated by ice and rocks protruding below the glacier sole, is water-saturated and has low shear strength. Till below is dewatered, over-consolidated, and impermeable. Creep occurs in the sheared, dilatant till, and to a much lesser degree in the underlying consolidated till. Sliding occurs at the ice-sediment contact or at a failure plane in the till. Virtually no creep occurs in the glacier ice. High water pressures reflect the low permeability of the till; water flows into pore space during shearing and dilation, but is then essentially confined as the till begins to be re-compacted by the glacier load. This model agrees well with observations of thin zones of sheared, weak till beneath glaciers (Boulton and others, 1974; Baranowski, 1975) and with what is known about the highly variable geotechnical properties of tills (Fig. 1).

\section{SUMMARY AND CONCLUSIONS}

This paper demonstrates that the yield strength of a large Pleistocene till debris flow near Macon, Illinois, composed of coeval Shelbyville till, was approximately $8 \pm 2 \mathrm{kPa}$. There is nothing unique or unusual about the sedimentology or texture of the Shelbyville drift; the Laurentide ice sheet deposited similar clayey or clayey silty till over much of the southern Great Lakes area (Mickelson and others, 1983, p. 7) and western Canada. The recognition of Pleistocene till with low shear strength supports the thesis of Boulton and Jones (1979) that the Laurentide ice sheet over part or all of the southern Great Lakes area may have been unusually thin due to significant deformation of subglacial sediment at low shear stresses. Low-profile lobes of Laurentide ice identified on the western plains of North America and in Arctic Canada support and expand this hypothesis, indicating that a significant portion of the perimeter of the Laurentide ice sheet was unusually thin, and that low profiles extended hundreds of kilometers in from the glacial periphery.

A theoretical profile generated by assuming plastic deformation of subglacial till beneath the Pleistocene Lake Michigan lobe of the Laurentide ice sheet is thinner than profiles of most modern ice sheets, but it is consistent with field data on actual glacier thickness. Low glacier profiles mapped on the north-west, west, south-west, and southern flanks of the Laurentide ice sheet may also reflect plastic deformation of basal tills with low yield strengths.

Irregularities at the base of a glacier will disrupt a thin zone of basal till during glacier sliding, maintaining a zone of high porosity near the ice-till boundary. High pore-water pressures in sheared, low-permeability, clayey till can partially support the glacial load, reducing effective normal stress. Water-saturated tills have much less strength than ice.

\section{ACKNOWLEDGEMENTS}

Drafts of this paper were reviewed by L. Shapiro, W. Harrison, D. Hopkins, M. Sturm, and M. Keskinen of the University of Alaska. I gratefully acknowledge their help. I also thank D. Turner and G. Wescott of the University of Alaska Geophysical Institute, and C. Nye of the A.D.G.G.S., who invited me to visit their field camp at Mount Spurr, Alaska, where I was able to observe deformation in basal till below an active glacier snout.

\section{REFERENCES}

Andrews, J.T. 1973. The Wisconsin Laurentide ice sheet: dispersal centers, problems of rates of retreat, and climatic implications. Arctic and Alpine Research, Vol. 5, No. 3, p. 185-99.

Andrews, J.T. [1975.] Glacial systems; an approach to glaciers and their environments. North Sciutate, MA, Duxbury Press.

Baranowski, S. 1975. Glaciological investigations and glaciomorphological observations made in 1970 on Werenskiold glacier and its forefield. Acta Universitatis Wratislaviensis, No. 251, p. 69-94.

Beget, J. In press. Low profile of the northwest Laurentide ice sheet. Journal of Arctic and Alpine Research.

Birchfield, G.E., and Grumbine, R.W. 1985. "Slow" physics of large continental ice sheets and underlying bedrock and its relation to the Pleistocene ice ages. Journal of Geophysical Research, Vol. 90, No. B13, p. 11294-302.

Birkeland, P.W. 1984. Soils and geomorphology. Oxford, Oxford University Press.

Boulton, G.S. 1982. Subglacial processes and the development of glacial bedforms. (In Davidson-Arnott, R., and others, eds. Research in glacial, glacio-fluvial and glacio-lacustrine systems; proceedings of the 6th Guelph Symposium on Geomorphology 1980, edited by $R$. Davidson-Arnott, W. Nickling, and B.D. Fahey. Norwich, Geo Books, p. 1-31.) 
Boulton, G.S., and Jones, A.S. 1979. Stability of temperate ice caps and ice sheets resting on beds of deformable sediment. Journal of Glaciology, Vol. 24, No. 90, p. 29-43.

Boulton, G.S., and Paul, M.A. 1976. The influence of genetic processes on some geotechnical properties of glacial tills. Quarterly Journal of Engineering Geology, Vol. 9, No. 3, p. 159-94.

Boulton, G.S., and Vivian, R. 1973. Underneath the glaciers. Geographical Magazine, Vol. 45, No. 4, p. 311-16.

Boulton, G.S., and others. 1974. Subglacial shearing and crushing, and the role of water pressures in tills from south-east Iceland, by G.S. Boulton, D.L. Dent, and E.M Morris. Geografiska Annaler, Vol. 56A, No. 3-4, p. 135-45.

Brunn, V. von. 1977. A furrowed intratillite pavement in the Dwyka Group of northern Natal. Transactions of the Geological Society of South Africa, Vol. 80, p. 125-30.

Brunn, V. von., and Talbot, C.J. In press. Formation and deformation of subglacial intrusive clastic sheets in the Dwyka Formation of northern Natal, South Africa. Journal of Sedimentary Petrology.

Clayton, L., and others. 1985. Surging of the southwestern part of the Laurentide ice sheet, by L. Clayton, J.T Teller, and J.W. Attig. Boreas, Vol. 14, No, 3 , 235-41.

Cowan, D.S., and Mansfield, C.F. 1970. Serpentinite flows on Joaquin Ridge, Southern Coast Ranges, California. Geological Society of America. Bulletin, Vol. 81, p. 2615-28.

Dreimanis, A., and Vagners, U.J. [1971.] Bimodal distribution of rock and mineral fragments in basal tills. (In Goldthwait, R.P., ed. Till; a symposium. [Columbus, $\mathrm{OH}$, Ohio State University Press, p. 237-50.)

Flint, R.F. 1971. Glacial and Quaternary geology. New York, etc., John Wiley and Sons, Inc.

Gjessing, J. 1965. On 'plastic scouring' and 'subglacial erosion'. Norsk Geografisk Tidsskrift, Bd. 20, Ht. 1-2, p. $1-37$.

Haeberli, W. 1981. Ice motion on deformable sediments. Journal of Glaciology, Vol. 27, No. 96, p. 365-66.

Hampton, M.A. 1975. Competence of fine-grained debris flows. Journal of Sedimentary Petrology, Vol. 45, p. 834-44.

Harrison, W. 1958. Marginal zones of vanished glaciers reconstructed from the preconsolidation-pressure values of overridden silts. Journal of Geology, Vol. 66, p. 72-95.

Hester, N.C., and DuMontelle, P.B. [1971.] Pleistocene mudflow along the Shelbyville moraine front, Macon County, Illinois. (In Goldthwait, R.P., ed. Till; a symposium. [Columbus, $\mathrm{OH}$ ], Ohio State University Press, p. 367-82.)

Hicock, S.R., and Dreimanis, A. 1985. Glaciotectonic structures as useful ice-movement indicators in glacial deposits: four Canadian case studies. Canadian Journal of Earth Sciences, Vol. 22, No. 3, p. 339-46.

Hodge, S.M. 1976. Direct measurement of basal water pressures: a pilot study. Journal of Glaciology, Vol. 16, No. 74, p. 205-18.

Hodge, S.M. 1979. Direct measurement of basal water pressures: progress and problems. Journal of Glaciology, Vol. 23, No. 89, p. 309-19.

Hooke, R.L. 1977. Basal temperatures in polar ice sheets: a qualitative review. Quaternary Research, Vol. 7, No. 1, p. $1-13$.

Hoppe, G. 1952. Hummocky moraine regions with special reference to the interior of Norrbotten. Geografiske Annaler, Ârg. 34, Ht. 1-2, p. 1-72.

Huang, Y.H. 1983. Stability analysis of earth slopes. New York, Van Nostrand Reinhold Company, Inc.

Hughes, O.L. 1972. Surficial geology of northern Yukon Territory and northwestern District of Mackenzie, Northwest Territories. Canada. Geological Survey. Paper 69-36.

Hughes, T.J. 1985. The great Cenozoic ice sheet. Palaeogeography, Palaeoclimatology, Palaeoecology, Vol. 50, p. $9-43$.
Hughes, T.J., and others. 1981. The last great ice sheets: a global view, by T.J. Hughes, G.H. Denton, B.G. Andersen, D.H. Schilling, J.L. Fastook, and C.S. Lingle. (In Denton, G.H., and Hughes, T.J., eds. The last great ice sheets. New York, etc., Wiley-Interscience, p. 263-317.)

Jezek, K.C., and others. 1985. Rheology of glacier ice, by K.C. Jezek, R.B. Alley, and R.H. Thomas. Science, Vol. 227, No. 4692, p. 1335-37.

Johnson, A.M. 1970. Physical processes in geology. San Francisco, Freeman, Cooper and Co.

Jones, N. 1982. The formation of glacial flutings in eastcentral Alberta. (In Davidson-Arnott, R., and others, eds. Research in glacial, glacio-fluvial and glacio-lacustrine systems; proceedings of the 6th Guelph Symposium on Geomorphology 1980, edited by $R$. Davidson-Arnott, $W$. Nickling, and B.D. Fahey. Norwich, Geo Books, p. 49-70.)

Kamb, B., and others. 1985. Glacier surge mechanism: 1982-1983 surge of Variegated Glacier, Alaska, by B Kamb [and 7 others]. Science, Vol. 227, No. 4686, p. 469-79.

Kazi, A., and Knill, J.L. 1969. The sedimentation and geotechnical properties of the Cromer till between Happisburgh and Cromer, Norfolk. Quarterly Journal of Engineering Geology, Vol. 2, No. 1, p. 63-86.

King, P.B. 1965. Tectonics of Quaternary time in middle North America. (In Wright, H.E., and Frey, D.G., eds. The Quaternary of the United States. Princeton, Princeton University Press, p. 831-70.)

Lorrain, R.D., and Demeur, P. 1985. Isotopic evidence for relic Pleistocene glacier ice on Victoria Island, Canadian Arctic Archipelago. Arctic and Alpine Research, Vol. 17, No. 1, p. 89-98.

MacClintock, P., and Dreimanis, A. 1964. Reorientation of till fabric by overriding glacier in the St. Lawrence Valley. American Journal of Science, Vol. 262, No. 1, p. 133-42.

Mathews, W.H. 1964. Water pressure under a glacier. Journal of Glaciology, Vol. 5, No. 38, p. 235-40.

Mathews, W.H. 1974. Surface profiles of the Laurentide ice sheet in its marginal areas. Journal of Glaciology, Vol. 13 , No. 67 , p. $37-43$.

Menzies, J. 1979. The mechanics of drumlin formation with particular reference to the change in pore-water content of the till. Journal of Glaciology, Vol. 22, No. 87, p. 373-84.

Menzies, J. 1982. A till hummock (proto-drumlin) at the ice glacier bed interface. (In Davidson-Arnott, R., and others, eds. Research in glacial, glacio-fluvial and glacio-lacustrine systems; proceedings of the 6th Guelph Symposium on Geomorphology 1980, edited by $R$. Davidson-Arnott, W. Nickling, and B.D. Fahey. Norwich, Geo Books, p. 33-47.)

Mickelson, D.M., and others. 1983. The late Wisconsin glacial record of the Laurentide ice sheet in the United States, by D.M. Mickelson, L. Clayton, D.S. Fullerton, and H.W. Borns, jr. (In Wright, H.E., and Porter, S.C., eds. Late Quaternary environments of the United States. Vol. I. The Late Pleistocene. Minneapolis, University of Minnesota Press, p. 3-37.)

Milligan, V. [1976.] Geotechnical aspects of glacial tills. (In Legget, R.F., ed. Glacial till; an interdisciplinary study. [Ottawa], Royal Society of Canada, p. 269-91.)

Moran, S.R. [1971.] Glaciotectonic structure in drift. (In Goldthwait, R.P., ed. Till; a symposium. [Columbus, $\mathrm{OH}$, Ohio State University Press, p. 127-48.)

Nielsen, P.E. 1981. Till fabric reorientated by subglacial shear. Geologiska Föreningens $i$ Stockholm Förhandlingar, Vol. 103, Pt. 3, p. 383-87.

Occhietti, S. 1973. Les structures et déformations engendrées par les glaciers - essai de mise au point. 1. Déformations et structures glaciotectoniques. Revue de Géographie de Montréal, Vol. 27, No. 4, p. 365-80.

Oldale, R.N., and O'Hara, C.J. 1984. Glaciotectonic origin of the Massachusetts coastal end moraines and a fluctuating late Wisconsinan ice margin. Geological Society of America. Bulletin, Vol. 95, p. 61-74.

Okko, V. 1955. Glacial drift in Iceland, its origin and morphology. Bulletin de la Commission Géologique de Finlande. No. 170. 
Oldale, R.N., and others. 1982. Stratigraphy, structure, absolute age, and paleontology of the upper Pleistocene deposits at Sankaty Head, Nantucket Island, Massachusetts, by R.N. Oldale [and 7 others]. Geology, Vol. 10, p. 246-52.

Paterson, W.S.B. 1981. The physics of glaciers. Second edition. Oxford, etc., Pergamon Press. (Pergamon International Library.)

Radhakrishna, H.S., and Klym, T.W. 1974. Geotechnical properties of a very dense glacial till. Canadian Geotechnical Journal, Vol. 11, No. 3, p. 396-408.

Rampton, V.N. 1982. Quaternary geology of the Yukon coastal plain. Canada. Geological Survey of Canada. Bulletin 317

Ramsden, J., and Westgate, J.A. 1971. Evidence for reorientation of a till fabric in the Edmonton area, Alberta. (In Goldthwait, R.P., ed. Till; a symposium. [Columbus, $\mathrm{OH}$ ], Ohio State University Press, p. 335-44.)

Rodine, J.D., and Johnson, A.M. 1976. The ability of debris, heavily freighted with coarse clastic materials, to flow on gentle slopes. Sedimentology, Vol. 23, p. 213-34.

Röthlisberger, H., and others. 1979. Piezometric observations of water pressure at the bed of Swiss glaciers, by $\mathrm{H}$. Röthlisberger, A. Iken, and U. Spring. Journal of Glaciology, Vol. 23, No. 89, p. 429.

Selby, M.J. 1982. Hillslope materials and processes. Oxford, Oxford University Press.

Shreve, R.L. 1985. Late Wisconsin ice-surface profile calculated from esker paths and types, Katahdin esker system, Maine. Quaternary Research, Vol. 23, No. 1, p. 27-37.

Sladen, J.A., and Wrigley, W. 1983. Geotechnical properties of lodgement till. (In Eyles, N., ed. Glacial geology; an introduction for engineers and earth scientists. Oxford etc., Pergamon Press, p. 184-212.)
Smalley, I.J., and Unwin, D.J. 1968. The formation and shape of drumlins and their distribution and orientation in drumlin fields. Journal of Glaciology, Vol. 7, No. 51, p. 377-90.

Sønstegaard, E. 1979. Glaciotectonic deformation structures in unconsolidated sediments at Os, south of Bergen. Norsk Geologisk Tidsskrift, Vol. 59, No. 3, p. 223-28.

Stalker, A.M. 1960. Surficial geology of the Red Deer-Stettler map-area, Alberta. Canada. Geological Survey. Memoir 306.

Sugden, D.E. 1977. Reconstruction of the morphology, dynamics, and thermal characteristics of the Laurentide ice sheet at its maximum. Arctic and Alpine Research, Vol. 9, No. 1, p. 21-47.

Thomas, G.S.P., and Connell, R.J. 1985. Iceberg drop, dump, and grounding structures from Pleistocene glacio-lacustrine sediments, Scotland. Journal of Sedimentary Petrology, Vol. 55, p. 243-49.

Visser, J.N.J., and Hall, K.J. 1985. Boulder beds in the glaciogenic Permo-Carboniferous Dwyka Formation in South Africa. Sedimentology, Vol. 32, p. 281-94.

Walcott, R.I. 1972. Late Quaternary vertical movements in eastern North America: quantitative evidence of glacio-isostatic rebound. Reviews of Geophysics and Space Physics, Vol. 10, p. 849-84.

Weertman, J. 1979. The unsolved general glacier sliding problem. Journal of Glaciology, Vol. 23, No. 89, p. 97-115.

Westgate, J.A. 1968. Surficial geology of the Foremost-Cypress Hills area, Alberta. Research Council of Alberta. Bulletin 22.

Wright, H.E. 1973. Tunnel valleys, glacial surges, and subglacial hydrology of the Superior lobe, Minnesota. Geological Society of America. Memoir 136. 